\title{
Colonic Abrikossoff tumor: fortuitous discovery at colonoscopy for serrated adenomas polyposis, and resection by endoscopic submucosal dissection
}

Granular cell tumors (GCTs) are a type of submucosal tumor, with an overall soft tissue tumor incidence of $0.03 \%$ [1]. They are benign neural tumors presenting typically in the dermis or subcutis, in adults, and more frequently in women.

Amongst all GCTs, $5 \%-11 \%$ occur in the gastrointestinal (Gl) tract. The second most commonly affected Gl organ is the colon (20\%) and GCTs may be located anywhere in it [2].

Colonic GCTs typically appear as yellowish firm lesions with intact mucosa but they can also be sessile or pedunculated polyps. Patients may have additional findings on colonoscopy, including adenomas and hyperplasic polyps, which are likely unrelated to the presence of GCTs [3].

We report here the case of a 59-yearold woman who underwent a first colonoscopy for rectal bleeding, which led to a finding of serrated adenomas polyposis. A further colonoscopy was performed that revealed in the right colon, a small, white and yellowish submucosal

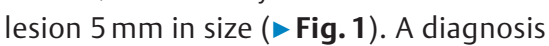
of small neuroendocrine tumor (NET) was initially proposed, and we used a strategy of endoscopic submucosal dissection (ESD) with traction using two clips and a rubber band [4]. Traction allowed the correct exposure of the submucosal lesion ( $\mathbf{V i d e o} \mathbf{1}, \mathbf{F i g . 2}$ ), and then the resection was en bloc and endoscopically complete.

Pathological examination ( $\mathbf{F i g . 3}$ ) revealed a well-circumscribed nodular tumor in the colonic submucosa composed of nests of tumor cells divided by slender fibrous septa. Cells were polygonal or spindle with a small nucleus and large eosinophilic cytoplasm with a distinctly granular appearance. These granules correspond to phagolysosomes. Immunohistochemical study showed diffuse S100 protein expression by tumor cells. Resection was complete with free margins (R0).
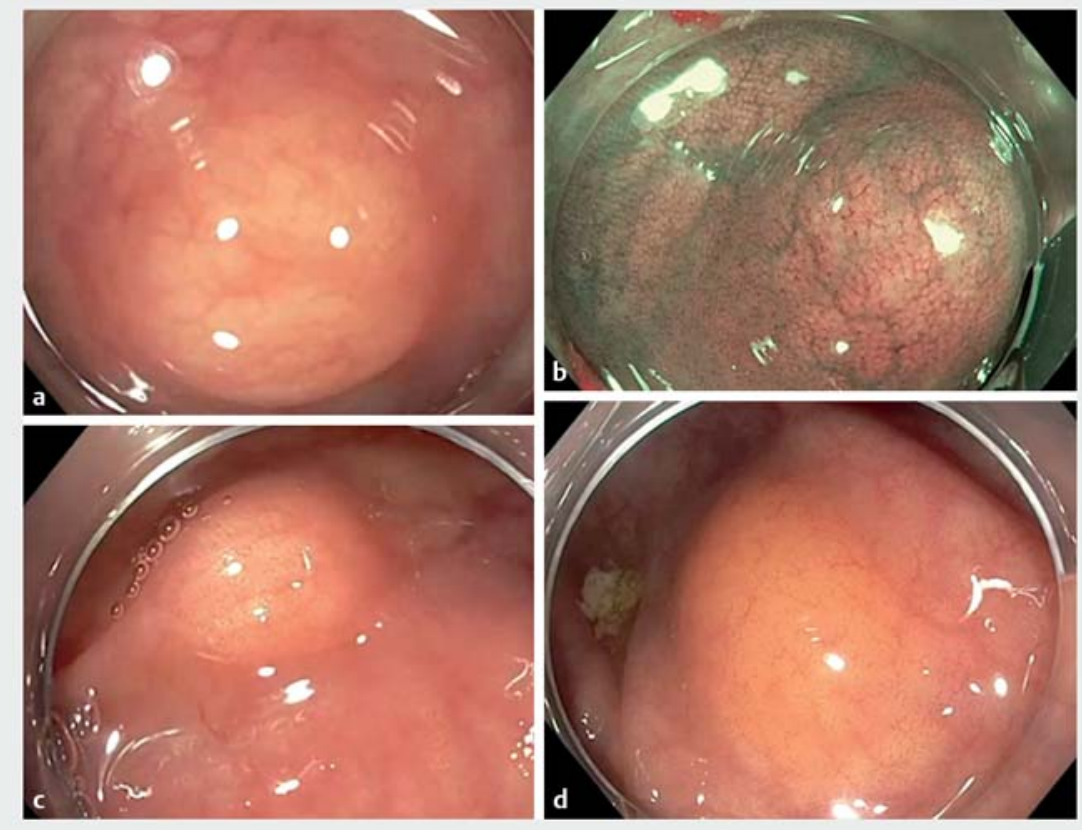

Fig. 1 Endoscopic appearances at second colonoscopy in a 59-year-old woman with a finding of serrated adenoma polyposis. a, c A granular cell tumor (GCT) in the right colon with white light imaging. $\mathbf{b}$ Same GCT with narrow band imaging. $\mathbf{d}$ Differing appearance of a lipoma in the cecum.
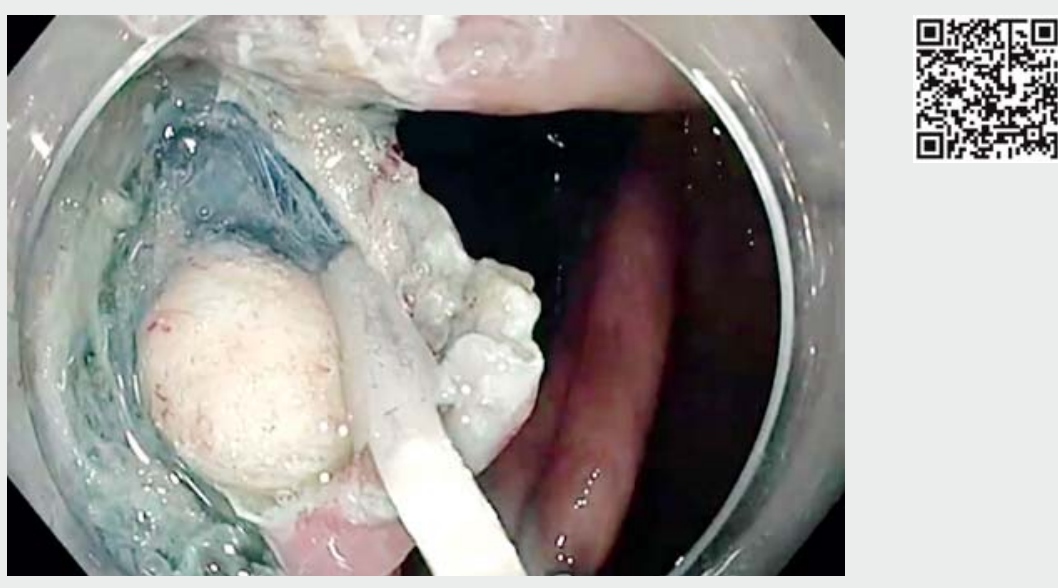

$\checkmark$ Video 1 Endoscopic submucosal dissection (ESD) of a granular cell tumor. 

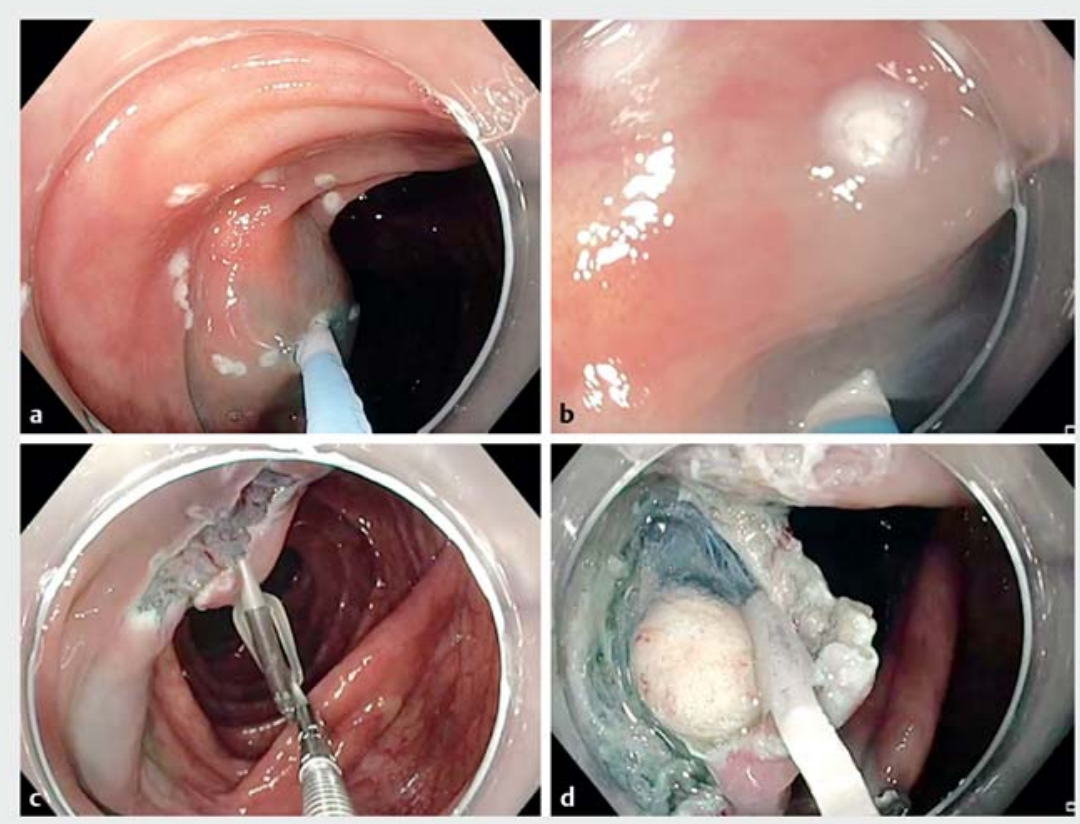

Granular cell tumors are rare in the Gl tract, occurring with differing endoscopic features and difficult to distinguish from NETs. Endoscopic submucosal dissection may allow a complete resection of the lesion to facilitate the pathology analysis.

Endoscopy_UCTN_Code_CCL_1AD_2AC

\section{Competing interests}

None

Fig. 3 Pathological examination of granular cell tumor. a Nodular tumor in the submucosa of the colon wall (hematoxylin and eosin [H\&E] and safranin, original magnification $\times 1$ ). b Tumor cells with large eosinophilic cytoplasm and a distinctly granular appearance (H\&E and safranin, original magnification $\times 25$ ). c S100 expression in tumor cells (original magnification $\times 15$ ). 
Margot Biscay ${ }^{1}$, Edouard Chabrun ${ }^{1,2}$, Sarah Menguy $^{3}$, Elodie Cesbron-Métivier ${ }^{3,4}$, Marc Barthet $^{2,5}$, Marion Marty ${ }^{3}$, Mathieu Pioche ${ }^{2,6}$

1 Department of Endoscopy and Gastroenterology, Haut-Lévêque University Hospital, Bordeaux, France

2 French Society of Digestive Endoscopy, SFED, Paris, France

3 Department of Anatomopathology, HautLévêque University Hospital, Bordeaux, France

4 Department of Endoscopy and Gastroenterology, Angers University Hospital, Angers, France

5 Department of Endoscopy and Gastroenterology, Hôpital Nord, Assistance Publique des Hôpitaux de Marseille, France

6 Department of Endoscopy and Gastroenterology, Pavillon L, Edouard Herriot Hospital, Lyon, France
Corresponding author

\section{Mathieu Pioche, MD}

Endoscopy Unit - Digestive Disease

Department, Pavillon L - Edouard Herriot

Hospital, 69437 Lyon Cedex, France

Fax: +33-4-72110147

mathieu.pioche@chu-lyon.fr

\section{References}

[1] Lack EE, Worsham GF, Callihan MD et al. Granular cell tumor: a clinicopathologic study of 110 patients. J Surg Oncol 1980; 13: 301-316

[2] Chen Y, Chen Y, Chen X et al. Colonic granular cell tumor: Report of 11 cases and management with review of the literature. Oncol Lett 2018; 16: 1419-1424

[3] Barakat M, Kar AA, Pourshahid S et al. Gastrointestinal and biliary granular cell tumor: diagnosis and management. Ann Gastroenterol 2018; 31: 439-447

[4] Lupu A, Jacques J, Rivory J et al. Endoscopic submucosal dissection with triangulated traction with clip and rubber band: the “wallet" strategy. Endoscopy 2018; 50: E256 - E258 [Epub 2018 Jun 28]

\section{Bibliography}

DOI https://doi.org/10.1055/a-0871-2266

Published online: 1.4.2019

Endoscopy 2019; 51: E176-E178

(c) Georg Thieme Verlag KG

Stuttgart · New York

ISSN 0013-726X

\section{ENDOSCOPY E-VIDEOS}

https://eref.thieme.de/e-videos

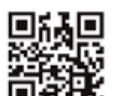

Endoscopy E-Videos is a free access online section, reporting on interesting cases and new

techniques in gastroenterological endoscopy. All papers include a high quality video and all contributions are freely accessible online.

This section has its own submission website at https://mc.manuscriptcentral.com/e-videos 